\title{
Breast Cancer pN1c TNM Finding v6
}

National Cancer Institute

\section{Source}

National Cancer Institute. Breast Cancer pN1c TNM Finding v6. NCI Thesaurus. Code C49000.

Breast cancer with metastasis in 1 to 3 axillary lymph nodes and in internal mammary nodes with microscopic disease detected by sentinel lymph node dissection but not clinically apparent. (from AJCC 6th Ed.) 